\section{Uticaj preoperativne}

administracije finasterida

na perioperativno krvavljenje

tokom transuretralne vapor

resekcije prostate

Argirović M. Đorđe ${ }^{1}$, Argirović Đ. Aleksandar ${ }^{2}$

${ }^{1}$ Poliklinika "Argirović", Urologija, Beograd, Srbija

${ }^{2}$ Služba urologije, Kliničko bolnički centar Zemun-Beograd,

Beograd, Srbija

\section{Apstrakt}

Ispitivano je koliko finasterid dat pre transuretralne vapor resekcije prostate (TUVRP) ima uticaja na intra- i postoperativno krvavljenje. Četrdeset dva pacijenta sa dijagnozom benigne hiperplazije prostate (BHP) koji su imali volumen prostate $(\mathrm{VP})>30 \mathrm{~mL}$ su podvrgnuti TUVRP: grupa A $(\mathrm{n}=21)$ je primala preoperativno $5 \mathrm{mg}$ finasterida dnevno tokom srednjeg perioda of 7 meseci i grupa $B(n=21)$ bez finasterida. Preoperativna evaluacija je podrazumevala odredjivanje Internacionalnog Prostata Simptom skora (IPSS), ocenu kvaliteta života (KŽ), maksimalnog protoka urina (MPU) i rezidualnog urina posle mokrenja (RU). Srednja starost pacijenata je bila $71.4 \pm 2.1$ prema $69.8 \pm 3.4$ godina. Srednji VP je bio $55.5 \pm 21.2$ prema $57.1 \pm 28.8 \mathrm{~mL}$. Dvadeset dva (52\%) pacijenta su imala kompletnu retenciju $(29 \%$ prema $76 \%)(\mathrm{p}<0.001)$. Inicijalno srednji IPSS, KŽ, MPU i RU su bili $18.1 \pm 5.9$ prema $19.8 \pm 5.04,3.3 \pm 1.7$ prema $3.3 \pm 1.7,8.1 \pm 4.4$ prema $6.9 \pm 1.6 \mathrm{~mL} / \mathrm{s}$ i $146 \pm 106.9$ prema $151.6 \pm 112.1$ $\mathrm{mL}$. Srednje trajanje operacije je iznosilo $59 . \pm 16.8$ prema $64 \pm 19.2 \mathrm{~min}$, srednji volumen tečnosti za ispiranje intraoperativno je iznosio $14.1 \pm 7.01$ prema $15.2 \pm 8.1 \mathrm{~L}$ i postoperativno $7.0 \pm 2.1$ prema $8.1 \pm 1.3$ L. Srednja težina reseciranog tkiva je iznosila 31.3 \pm 5.8 prema $30.75 \pm 8.4$ gr. Srednji gubitak krvi je bio $312 \pm 85.9$ prema $425 \pm 68.5 \mathrm{~mL}$. Srednje trajanje postoperativnog ispiranja je iznosilo $6.1 \pm 4.7$ prema $6.2 \pm 5.1$ časova. Trideset i šest $(85.7 \%)$ pacijenata je otpušteno unutar $12 \mathrm{~h}$ postoperativno, kateter je izvadjen posle $2.0 \pm 0.5$ prema $2.5 \pm 0.6$ dana. $\mathrm{Ni}$ jedan pacijent nije primio transfuziju krvi. $\mathrm{Na} 3$ meseca postoperativno IPSS je bio $6.7 \pm 4.2$ prema

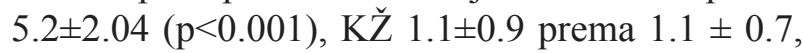
MPU $18.1 \pm 10.3$ prema $17.5 \pm 8.1 \mathrm{~mL} / \mathrm{s}(\mathrm{p}<0.01)$ i RU $41 \pm 46.1$ prema $45 \pm 51.3 \mathrm{~mL}(\mathrm{p}<0.05)$. Ova studija je

\section{Impact of preoperative administration of finasteride on perioperative bleeding during transurethral vapor resection of the prostate}

\author{
Argirovic M. Djordje ${ }^{1}$, Argirovic Dj. Aleksandar ${ }^{2}$ \\ ${ }^{1}$ Outpatient Clinic “Argirović”, Urology, Belgrade,Serbia \\ ${ }^{2}$ Department of Urology. Clinical Hospital Center \\ Zemun-Belgrade, Belgrade
}

\section{Abstract}

We investigated whether finasteride given before transurethral vapor resection (TUVRP) treatment has an impact on intra- and postoperative bleeding. Forty-two patients with diagnosis of benign prostatic hyperplasia (BPH) who had prostate volume $(\mathrm{PV})>30 \mathrm{~mL}$ underwent TUVRP: group $\mathrm{A}(\mathrm{n}=21)$ received preoperatively finasteride $5 \mathrm{mg}$ per day for median time of 7 months and group $B(n=21)$ no finasteride. Preoperative evaluation include assessment of International Prostatic Symptom score (IPSS), Quality of Life (QoL), PV, maximum flow rate (Qmax) and postvoid residual (PVR). Patients mean age was $71.4 \pm 2.1$ vs 69.8 vs \pm 3.4 years, respectively. Median PV was $55.5 \pm 21.2$ vs 57.1 $\pm 28.8 \mathrm{~mL}$, respectively. Twenty-two (52\%) patients had complete retention $(29 \%$ vs $76 \%)(p<0.001)$. At baseline mean IPSS, QoL, Qmax and PVR were $18.1 \pm 5.9$ vs $19.8 \pm 5.04,3.3 \pm 1.7$ vs $3.3 \pm 1.7,8.1 \pm 4.4$ vs $6.9 \pm 1.6 \mathrm{~mL} / \mathrm{s}$, and $146 \pm 106.9$ vs $151.6 \pm 112.1 \mathrm{~mL}$, respectively. The mean operation time was $59 \pm 16.8$ vs $64 \pm 19.2 \mathrm{~min}$, mean volume of irrigation fluid intraoperatively was $14.1 \pm 7.01$ vs $15.2 \pm 8.1 \mathrm{~L}$ and postoperatively $7.0 \pm 2.1$ vs $8.1 \pm 1.3 \mathrm{~L}$, respectively. Mean blood loss was $312 \pm 85.9$ vs $425 \pm 68.5 \mathrm{~mL}$, respectively. The mean weight of resected tissue was $31.3 \pm 5.8$ vs $30.75 \pm 8.4$ gr, respectively. Mean duration of postoperative irrigation was $6.1 \pm 4.7$ vs $6.2 \pm 5.1 \mathrm{~h}$, respectively. Thirty-six $(85.7 \%)$ patients were discharged within $12 \mathrm{~h}$ postoperatively and the catheter is removed on $2.0 \pm 0.5$ vs $2.5 \pm 0.6$ days, respectively. No patients received blood transfusion postoperatively. At 3 months postoperatively IPSS was $6.7 \pm 4.2$ vs $5.2 \pm 2.01(\mathrm{p}<0.001)$, QoL $1.1 \pm 0.9$ vs $1.1 \pm 0.7, Q \max 18.1 \pm 10.3$ vs $17.5 \pm 8.1$ $\mathrm{mL} / \mathrm{s}(\mathrm{p}<0.01)$ and PVR $41 \pm 46.1$ vs $45 \pm 51.3 \mathrm{~mL}$ $(\mathrm{p}<0.05)$. The present study failed to demonstrate 
pokazala da preoperativni tretman BHP sa finasteridom nema značajan uticaj na smanjenje perioperativnog krvavljenja kod TUVRP.

Ključne reči: krvavljenje, finasterid, transuretralna vapor resekcija prostate that preoperative treatment of $\mathrm{BPH}$ with finasteride did not have significant impact of perioperative bleeding at TUVRP.

Key words: bleeding, finasteride, transurethral vapor resection of the prostate

\section{Introduction}

$\mathrm{BPH}$ is a progressive disease that occurs in many men. It is well known that prostate volume increase with age $^{1}$ and over time causes an age related impact on symptoms requiring pharmacological or surgical intervention $^{2,3}$. TURP remains the gold standard for the relief of infravesical obstruction and lower urinary tract symptoms (LUTS). The most prevalent peri- and postoperative complications of TURP include urinary retention, bleeding requiring transfusion and clot retention ${ }^{4,5}$. The previously published study revealed that TUVRP is associated with low blood loss, less irrigation requirement, was safe in patients with comorbid conditions and can be performed on ambulatory basis ${ }^{6}$.

Finasteride, a 5-alpha-reductase inhibitor (5ARI), is well known to reduce gross hematuria secondary to prostate bleeding associated with LUTS ${ }^{7,8,9}$. Hyperplasia of the prostatic tissue involves the action of dihydrotestosterone (DHT), which is derived from testosterone by action of 5AR. Inhibition of 5AR reduces the concentration of DHT in the prostate, leading to a reduction in PV, improved Qmax, decline in the incidence of acute urinary retention and the need for surgery ${ }^{10}$.

In this prospective non-randomized and not placebo-controlled study, we investigated wheter finasteride given before TUVRP as one day treatment would affect perioperative blood loss, operative time, resected volume, total irrigant requirement, duration of postoperative catheterization, Qmax, PVR and symptom relief.

\section{Material and Methods}

From January, 2003 to December, 2008, 42 patients with LUTS due to bladder outlet obstruction secondary to BPH underwent TUVRP in regional anesthesia. The patients with PV $>30 \mathrm{~cm}$ were divided into 2 therapeutic groups: group $A(n=21)$ received preoperatively finasteride $5 \mathrm{mg}$ per day for median period of 7 months (range 3-27) and group B (n=21) no finasteride. All patients were preoperatively investigated by means of digital rectal examination (DRE), IPSS, QoL, Qmax, PVR and PV mainly by transrectal ultrasound (TRUS). Patients with symptomatic obstructive BPH (DRE and transabdominal US/TRUS not suspicious, PSA $<4 \mathrm{ng} / \mathrm{mL}$ or benign prostatic biopsy), IPSS $>18$, Qol $>3$, Qmax $<12 \mathrm{~mL} / \mathrm{s}$, PVR $>100 \mathrm{~mL}$ were included in the study. Preoperative laboratory investigations included urine analysis, urine culture, complete blood cell counts, serum electrolyte levels, renal function test and serum prostate-specific antigen (PSA) test. Complete blood cell counts and tests to determine serum electrolyte levels were repeated within 6 hours postoperatively to check for changes in serum concentrations. Patients with PV $>100 \mathrm{~mL}$, neurogenic micturition disorders, bladder stone, bladder andor prostate cancer, urethral stricture, diabetes mellitus with poor control of disease and diabetic neuropathy, were not included in this study.

All patients signed an informed consent form for the surgery. The procedure was performed after preliminary cystoscopy and urethral dilatation to $\mathrm{Ch} 28$. A Ch 26/27 Storz resectoscope with Martin M400 and Erbe ICC-350 electrocautery with Storz vapor cut electrode was used. The electrosurgical generator was set to $110-$ $130 \mathrm{~W}$ for cutting and 50-80 W for coagulation. The vapor cut resection technique follows the same principles as described for modified Nesbit technique. The motion of loop is, however, slowed to allow for maximal simultaneous coagulation, vaporization, and resection of tissue. Although large bleeding vessels at the bladder neck and close to the capsule required coagulation, the general ooze during the procedure was reduced. Intraoperative blood loss was estimated by the indicator dilution method. The irrigant fluid was stirred intermittently during the procedure to prevent clotting. Three $5 \mathrm{~mL}$ samples of the fluid were sent for hemoglobin 
and sodium estimation using flame photometer. The average of three values was calculated, and the total blood loss measure was adjusted for the volume of irrigant fluid used. Volume of intraoperative irrigation fluid and operative time were calculated from the introduction of the resectoscope to placement of catheter at the end of the surgical procedure. Postoperatively, the irrigation was stopped after 4 to 12 hours, depending on the color of the returning fluid. The patients were mainly discharged from the office within $24 \mathrm{~h}$ following TUVRP and the catheter was removed few days latter. The weight of the resected tissue, intraoperative complications, and postoperative catheterization time were recorded. All resected specimens were sent for histological examination. Patients were reviewed 3 months postoperatively, and latter every 3 months during the first year postoperatively for evaluation with determination of IPSS, QoL, Qmax and measurement of PVR.

\section{Statistics}

All parameters are expressed as mean standard deviation (SD). Difference between preoperative and postoperative values within a treatment groups were determinate by Student's T test. The chi-square test was used for categorical data. A p value of 0.05 or less was considered statistically significant.

\section{Results}

Review of cumulative patient's characteristics is reported in the Table 1.

\begin{tabular}{|l|c|}
\hline \multicolumn{1}{|c|}{ Parameters } & Mean (SD, range) \\
\hline Age (years) & $70.6(7.02,60-84)$ \\
\hline Symptom duration & 2 months - 7 years \\
\hline IPSS total score & $20(4.7,15-35)$ \\
\hline QOL & $3.9(1.7,3-5)$ \\
\hline PV & $56.3(17.8,30-95)$ \\
\hline Qmax (ml/s) & $7.1(1.7,4-11)$ \\
\hline PVR (ml) & $116(85.66,90-800)$, median 104 \\
\hline Comorbidities (no) & 3 \\
\hline Coronary artery disease & 2 \\
\hline Chronic obstructive airways disease & 5 \\
\hline Hypertension & 4 \\
\hline Diabetes mellitus & \\
\hline
\end{tabular}

Table 1. Review of cummulated patients characteristics

Patients mean age was $71.3 \pm 2.1$ vs $69.8 \pm 3.4$ years, respectively (7 [17\%] were more than 80 years of age). Mean PV was $55.5 \pm 21.2 \mathrm{~mL}$ (range $30-90$ ) vs $57.1 \pm 28 \mathrm{~mL}$ (range $30-35$ ) (>50 mL in $62 \%$ vs $57 \%$ ). Among 7 (33.3\%) patients in group A, PV decreased in average of $25 \%$ occurred. Group A demonstrated PSA reduction in average of $32 \%(6.3 \pm 1.2$ to $4.2 \pm 1.3)$ before and after treatment vs no difference in group B ( $4.7 \pm 2.1$ to $4.3 \pm 2.6)$. Twenty-two (52\%) patients had complete retention $(29 \%$ vs $76 \%)(\mathrm{p}<0.001)$. Six $(14.3 \%)$ patients had TRUS biopsy of the prostate preoperatively with negative finding $(4.8 \%$ vs $23.8 \%)(p<0.001)$. Perioperative and postoperative characteristics were reported in the Table 2. 


\begin{tabular}{|l|c|c|c|}
\hline \multicolumn{1}{|c|}{ Parameters } & $\begin{array}{c}\text { Group A } \\
\text { Mean (SD, range) }\end{array}$ & $\begin{array}{c}\text { Group B } \\
\text { Mean (SD, range) }\end{array}$ & p \\
\hline Procedural time (min) & $59(16.8,40-115)$ & $64(19.2,25-94)$ & $\mathrm{ns}$ \\
\hline Irrigation volume intraop (lit) & $14.1(7.01,2.5-40)$ & $15.2(8.1,2.5-48)$ & $\mathrm{ns}$ \\
\hline Irrigation volume postop (lit) & $7.0(2.1,3-37)$ & $8.1(1.3,3-45)$ & $\mathrm{ns}$ \\
\hline Duration of postop irrigation (hours) & $6.1(4.7,1-12)$ & $6.2(5.1,2-14)$ & $\mathrm{ns}$ \\
\hline Catheter removal (days) & $2.0(1.5,1-5)$ & $2.25(0.78,1-4)$ & $\mathrm{ns}$ \\
\hline Resected weight of prostatic tissue (gr) & $31.3(8.5,22-85)$ & $30.75(8.4,22-51)$ & $\mathrm{ns}$ \\
\hline Intraoperative bleeding (mL) & $312(85,20-600)$ & $425(68,5-750)$ & $\mathrm{ns}$ \\
\hline Admission time ( days ) & $0.8(0.5,1-3)$ & $1.0(0.4,1-4)$ & $\mathrm{ns}$ \\
\hline Nursing conact time (min) & $36(8.2,20-50)$ & $45(9.1,30-90)$ & $\mathrm{ns}$ \\
\hline
\end{tabular}

TABLE 2. Perioperative and postoperative characteristics

Incidental prostate cancer was detected in $2(4.8 \%)$ patients, 1 patient in group A is referred to radical prostatectomy and 1 patient in group B underwent active surveillance. Two (4.8\%) patients developed postoperative bleeding within 2 and 12 hours (1 with clot formation), resolved by TUR for hemostasis. Two (4.8\%) patients developed prostate cancer at 24 and 45 months following TUVRP, successfully managed with radiation therapy. Table 3 . shows postoperative adverse events.

\begin{tabular}{|l|c|c|}
\hline \multicolumn{1}{|c|}{ Parameters } & $\begin{array}{c}\text { Group A } \\
\text { No ( \%) }\end{array}$ & $\begin{array}{c}\text { Group B } \\
\text { No ( \%) }\end{array}$ \\
\hline No recatheterized & $1(4.8)$ & - \\
\hline No transient dysuria & $2(9.5)$ & $3(14.3)$ \\
\hline No urinary tract infection & $1(4.8)$ & $1(4.8)$ \\
\hline No leg's deep vein thrombosis & $1(4.8)$ & - \\
\hline No urethral stricture & $2(9.5)$ & - \\
\hline No meatal stenosis & $1(4.8)$ & - \\
\hline No bladder neck sclerosis & $1(4.8)$ & - \\
\hline No incontinence & - & $-8)$ \\
\hline
\end{tabular}

Table 3. Total adverse events

None of patients received blood transfusion. Postoperative changes in sodium and hemoglobin level were $-2.0 \pm 0.5 \mathrm{vs}-2.1 \pm 0.8 \mathrm{mmol} / \mathrm{L}$ and $-1.2 \pm 0.8 \mathrm{vs}-1.3 \pm 0.7 \mathrm{mg} / \mathrm{dL}$, respectively. In 20 patients who were no in urinary retention preoperatively Qmax improved to $19.0 \pm 3.9 \mathrm{~mL} / \mathrm{s}$ vs $13.9 \pm 7.8 \mathrm{~mL} / \mathrm{s}$ in patients with permanent catheter preoperatively, and IPSS decreased to $5.1 \pm 4.2$ vs $5.2 \pm 2.1$, respectively. The effectiveness of the procedure was assessed at 3- and 12-months intervals postoperatively (Table 4.). 


\begin{tabular}{|l|c|c|c|c|c|c|c|}
\hline \multirow{2}{*}{} & \multicolumn{2}{|c|}{ Mean (SD) } & \multicolumn{2}{c|}{ Mean (SD) } & \multicolumn{2}{c|}{ Mean (SD) } & \multirow{2}{*}{ p } \\
\cline { 2 - 7 } & Group A & Group B & Group A & Group B & Group A & Group B & \\
\hline Months & \multicolumn{2}{|c|}{ Baseline } & \multicolumn{2}{|c|}{3} & \multicolumn{2}{|c|}{12} & \\
\hline No of pts & 21 & 21 & 21 & 21 & 19 & 18 & \\
\hline \multirow{2}{*}{ IPSS } & 19.1 & 20.8 & 5.1 & 5.2 & 5.2 & 5.3 & \multirow{2}{*}{$<0.001$} \\
& $(5.9)$ & $(5.4)$ & $(4.2)$ & $(2.1)$ & $(1.92)$ & $(2.7)$ & \\
\hline \multirow{2}{*}{ QOL } & 3.3 & 4.1 & 1.1 & 1.1 & 1.2 & 1.2 & \multirow{2}{*}{$<0.01$} \\
\hline \multirow{2}{*}{ Qmax } & $(1.7)$ & $(0.9)$ & $(0.9)$ & $(0.7)$ & $(0.6)$ & $(0.8)$ & \\
\hline \multirow{2}{*}{ PVR } & 8.1 & 6.9 & 18.1 & 17.5 & 18 & 17.1 & $<0.01$ \\
& $(4.4)$ & $(1.6)$ & $(10.3)$ & $(8.1)$ & $(2.7)$ & $(1.2)$ & \\
\hline
\end{tabular}

Table 4. Effectiveness of measures

After 12 months, IPSS was $5.2 \pm 1.92$ vs $5.3 \pm 2.7$, QoL $1.2 \pm 0.6$ vs $1.2 \pm 1.2 \pm 0 / 8$, Qmax $18.0 \pm 2.7$ vs $17.1 \pm 1.2$ $\mathrm{mL} / \mathrm{s}$ and PVR $47.1 \pm 50$ vs $48 \pm 10 \mathrm{ml}$, respectively. Statistical analysis using Student's T test shows significant symptom reduction $(\mathrm{p}<0.001)$, with improvement of Qmax, Qol and with decrease of PVR within 3 months after treatment $(\mathrm{p}<0.01)$. All other changes were significant at the $\mathrm{p}<0.01$ level. Two $(4.8 \%)$ patients underwent internal urethrotomy at 4 and 6 months postoperatively due to urethral stricture, and $1(2.4 \%)$ patient transurethral incision of the prostate due to bladder neck sclerosis. For a median follow up of 37.7 months the responder rate for the entire cohort of patients was as follows: $37(88 \%)$ patients were satisfied of the-

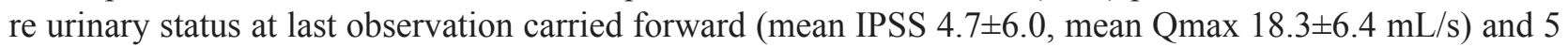
(12\%) patients were unsatisfied (mean IPSS 15.5 \pm 4.5 , mean Qmax 9.1 $\pm 2.8 \mathrm{~mL} / \mathrm{s}$ ).

\section{Discussion}

In this prospective study pretreatment with finasteride was inconclusive because it did not reveal any significant reduction in perioperative bleeding, although there was a trend towards a reduction with treatment: $312 \mathrm{~mL}$ in the catheter group compared with $425 \mathrm{~mL}$ in the control group. Few reports have shown a reduction in perioperative bleeding in large prostate ${ }^{10,11}$. However, our study had confirmed some other observation that finasteride have no impact on perioperative bleeding during TUVRP ${ }^{12}$. In many reports ${ }^{8,11}$ it has been shown that hematuria associated with BPH is related to increased vascularity of the prostate and it has been shown that angiogenesis can be suppressed by androgen deprivation. Finasteride has been shown to decrease the size of the prostate ${ }^{13,14}$. The present study demonstrated that decrease of PV occurred in average of $25 \%$ in $33 \%$ patients managed preoperatively with finasteride. We founded a fall in PSA level (by 33\%) in treated group as expected. The same finding occurs in other study ${ }^{12}$. The resected volume was the same in both groups; although this may seem low it only reflects reality, i.e. only the transition zone is resected. In other studies $^{11,15}$ the same resected volume was seen in average. None of our patients received a blood transfusion, whereas only 2 patients necessitate transurethral revision for hemostasis due to postoperative bleeding.

The proportion of incidentally diagnosed prostate cancers at the time of TURP has been demonstrated to be $10 \%{ }^{16}$, compared to $4.8 \%$ in our study. However, during follow-up of our patients, $2(4.8 \%)$ patients developed prostate cancer.

The results regarding the effectiveness of TUVRP strongly correlate with results published recently in the literature ${ }^{6,7}$. The technique of TUVRP was associated with minimal complications and shorter postoperative recovery. The postoperative bladder irrigation requirement was low, because the urine was usually clear 
in the immediate postoperative period. Nursing contact time was reduced and catheter was removed earlier. Postoperatively, there were a few incidence of dysuria, but dysuria resolved spontaneously. Reduction in blood loss, excellent vision, reduced operation time, less irrigant fluid requirement, the possibility to perform the procedure as one-day treatment in vast majority of patients, significantly reduce the cost of surgery.

\section{Conclusions}

The present study was inconclusive because it did not show significant benefit in terms of reducing bleeding during or after TUVRP following previous treatment with finasteride. TUVRP is safe and effective operation technique with minimal complications and faster postoperative recovery, and represent an advantage over standard method of TURP.

\section{Literature}

1. Emberton M. The hallmarks of BPH progression and risk factors. Eur Urol 2003; (Suppl 2):2-7.

2. Jacobsen SJ, Girman CJ, Guess HD, Oesterling JE, Lieber MM. New diagnostic and treatment guidelines for benign prostatic hyperplasia. Arch Intern Med 1995; 155: 477-81.

3. Nickal JC, Fradet Y, Boak RC, Pommerville PJ, Perreauly JP, Afridi SK et al. Efficacy and safety of finasteride therapy for benign prostatic hyperplasia: results of a 2-year randomized controlled trial (the PROSPECT study). PROscar Safety Plus Efficacy Canadian Two year Study. CMAJ 1996; 155:1215-9.

4. Roehrborn CG, McNicholas T. The management of prostatic obstruction: haw to determine the best options? Eur Urol 2003; (Suppl 2):13-9.

5. Mebust WK, Holtgrewe HL, Cockett AT, Peters PC. Writing Comitee, the American Urological Association. Transurethral prostatectomy: immediate and postoperatrive complications. Cooperative study of 13 participating institutions evaluating 3.885 patients. J Urol 1989; 141:243-9.

6. Gupta NP, Singh A, Kumar R. Transurethral vapor resection of prostate is a good alternative for prostate $>70 \mathrm{~g}$. J Endourol 2007; 21(12):1543-6.

7. Carlin BI, Bodner DR, Spinnak JP, Resnik MI. Role of finasterid in treatment of recurrent hematuria secondary to benign prostatic hyperplasia. Prostate 1997; 31:180-2.

8. Puchner PJ, Miller MI. The effect of finasteride on hematuria associated with benign prostatic hyperplasia: a preliminary report. J Urol 1995; 154:1779-82.

9. Sieber PR, Rommel FM, Huffnagle HW, Angusta VE, Harpster LE. The treatment of gross hematuria secondary to prostatic bleeding with finasteride. J Urol 1998; 159:1232-3.

10. Mc Connell JD, Stoner E. 5 alpha-reductase inhibitors. Adv Protein Chem 2001; 56: 143-8.

11. Hagerty JA, Ginsberg PC, Harmon JD, Harkaway RC. Pretreatment with finasteride decreases perioperative bleeding associated with transurethral resection of the prostate. Urology 2000; 55:684-7.

12. Lund L, Ernest-Jensen KL, Torring N, Nielsen JE. Impact of finasteride treatment of perioperative bleeding before transurethral resection of the prostate: A prospective randomized study. Scan J Urol Nephrol 2005; 39:160-2.

13. Gormley GJ, Stoner E, Bruskewitz RC. Imperato-McGinley J, Walsh PC, McConnell JD, et al. The effect of finasteride in men with benign prostatic hyperplasia. The Finasteride Study Group. N Engl J Med 1992; 327:1185-91.

14. Stoner E. The clinical effects of 5 alpha-reductase inhibitor, finasteride, on benign prostatic hyperplasia. The Finasteride Study Group. J Urol 1992; 147:1292-302. 
15. Donohue JF, Sharma H, Abraham R, Natalwale S, Thomas DR, Foster MC: Transurethral prostate resection and bleeding: a randomized, placebo controlled trial of the role of finasteride for decreasing operative blood loss. J Urol 2002; 168:2024-6.

16. Bostwick DG, Coner WH, Denis L, Jones GW, Scardino PT, Murphy GP: The association of benign prostatic hyperplasia and cancer of he prostate. Cancer 1992; (Suppl 1), 70: 291-301.

17. Patel A, Fuchs GJ, Guttierrez-Aceres J, Andrade-Perez F: Transurethral electrovaporization and vapour-rescetion of the prostate: An appraisal of possible electrosurgical after natives to regular loop resection. BJU Int 2000; 85: 202-10.

Corresponding author: Đorđe Argirović Outpatient Clinic “Argirović”, Urology 11.120 Belgrade

Serbia

Tel.: ++381 112788 498, 2788900

Fax.: ++ 381113290324

Mob.: ++ 38163236659

E-mail: cvijiceva@yubc.net 